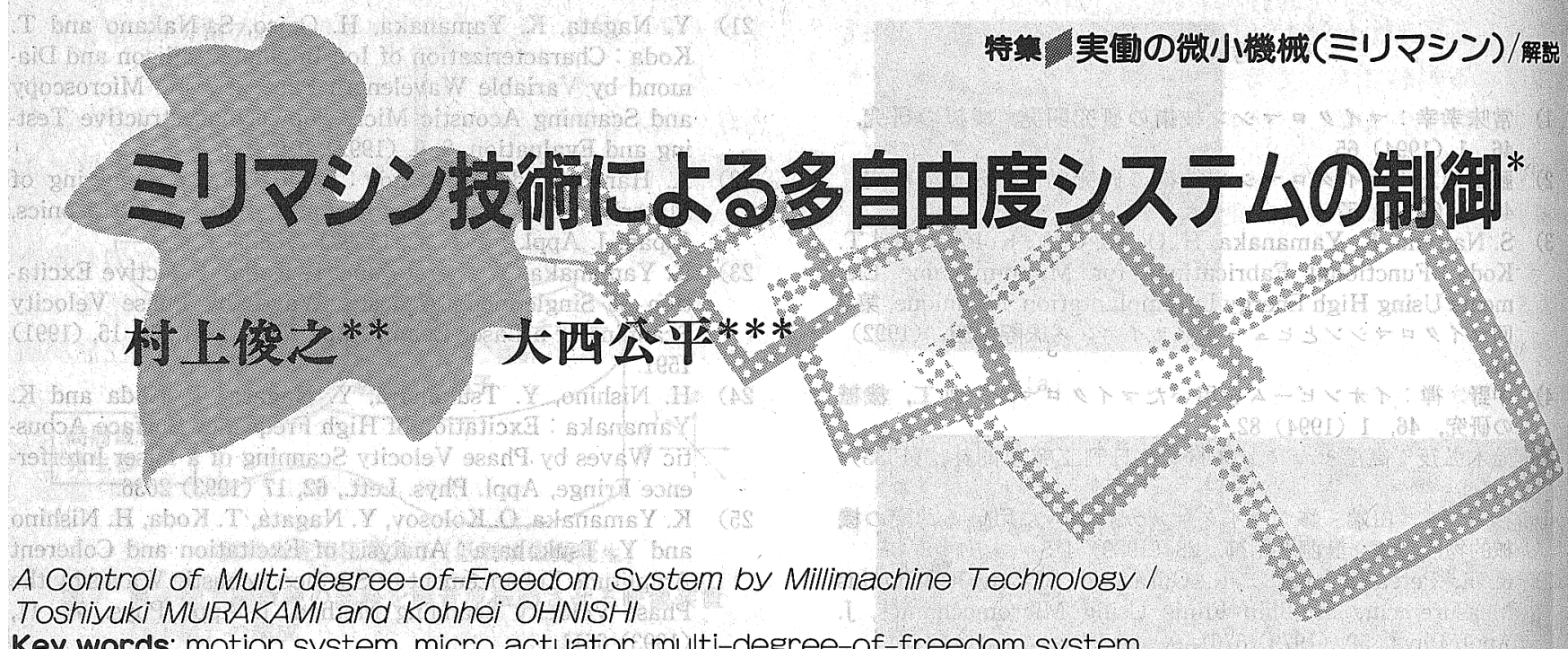

Key words: motion system, micro actuator, multi-degree-of-freedom system,

soliton, force transmission mechanism

\section{1.は ばめに}

本稿では，近年注目されているミリマンソ技術を利用す ることで可能となるであろら新たなロボットの機構技術, 制御技術について著者独自の観点から解説する.

産業用口ボットの導入により，各工場に和ける生産性の

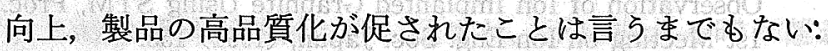
また, マイクロプロセサ拈よび制御技術の発達により口 ボット自身の制御性能も著しく向上している.すなわら， 現在のロボット（主に人間の腕を模擬したマニピュレー タ）に扣いて，その機構を最大限に生かしたマニピュレー ション技術が確立されているといっても過言ではない》。

一般に,これらの産業用口ボットは，あらかじめ教示され た作業をこなすために設計されて和り，作業内容に応じた 適応的な動作を行 万には困難な状況にある。しかしなが ら, 大量生産から多品種少量生産へ変遷しつつある現在の 産業界では，人間のように多機能でかつ柔軟な動作を行え るロボットの開発に関心が寄せられている.ー万, 現状の ロボットの構造では人間のよらにしなやかな動作を実現す ることが難しいことも周知のことである.これは,ロボッ ト自身の自由度が低しことに起因して扣り,ロボットの機

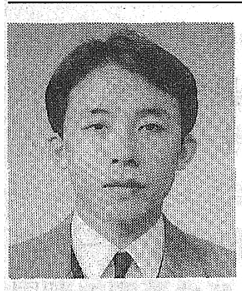

* 原稿受付 平成 5 年 12 月 20 日

** 慶應義塾大学理工学部（横浜市港北区日吉 314-1)

*** 正 会 員 慶應義塾大学理工学部 村上俊之

1993 年慶應義塾大学大学院後期博士課程修了, 工学博士. 同年同大学理工学部電気工学科助 手. 現在, ロボット扎よびモーションコント ロールに関する研究に従事 大西公平

1980 年東京大学大学院博士課程修了, 工学博 士. 現在, 慶應義塾大学理工学部電気工学科助 教授. 現在, モーションコントロールおよびパ ワーエレクトロニクスに関する研究に従事
構技術と密接に関係する。すなわち，所望の動作の実現精 度を低下させることなく，ロボット自身の自由度を高める ことが今後の課題としてクローズアップされる. そこで, 本稿ではミリマシン技術を導入した多自由度ンステムの满 成法を示し，その制御法について簡単に紹介する。ここ で，従来のミリマンン技術の着眼と異なる点は，ミリマン

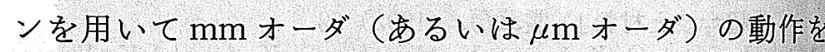
実現することが目的ではなく，本稿ではマク口な動作を実 現しようとしている点にある。

\section{2。多自由度システムの構成}

\section{1 多自由度システムの基本構成}

さて，自由度を増やすためにはロボットの構造をいが ずべきであろらか？ 直感的な発想では，従来のリンク機 構 (1つの関節により 2 つ上のリンクが結合され, 関節 に設置された1つ以上のアクチニエータにより駆動される 機構)を延長することで，多自由度なっボットを実現する ことができる。しかしながら，ロボットシステムが大規模 となるばかりでなく，各関節に存在するバックラッシュや フレキシビリティの影響が蓄積され，ロボット先端での位 置決め精度を向上することが困難となる。従って, 従来の リンク機構とは異なるロボットの構造を考察する必要があ る.ことで, 徒来のロホットを駆動方式の観点から再梌討 してみよう. 前述したよらに, ンンク機構からなるロボッ トは関節に設置されたアクチュエータ（電磁力を利用した サーボモータなど）により駆動される，いわゆる集中歌動 方式となっている. 集中駆動方式では, 機構の複雑化を招 かずにロボットの自由度を増やすことが可能であるが，基 本的にロボットシステムの規模が大きくなり，かつ出力/ 重量比が低くなるため效率的な駆動方式であるとは言い難 い.一方，集中駆動方式と対比して考えられる他の駆動方 


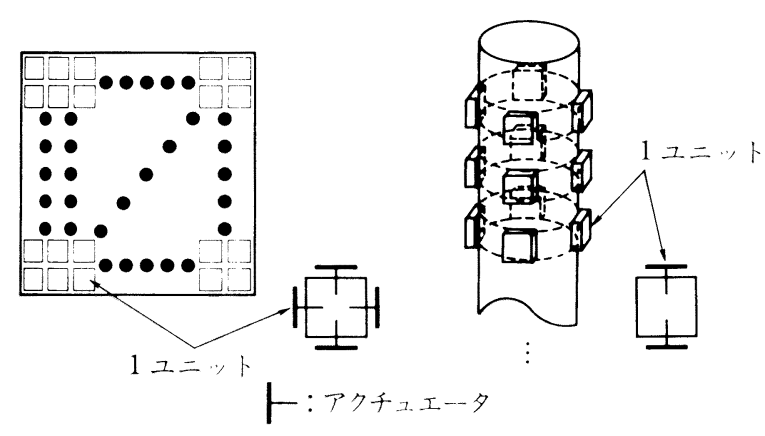

(a) 平面モデル

(b) 空間モデル

図 1 多自由度システムの構成法

式として分散駆動方式があげられる．分散駆動方式は，ア クチュエータ自身を小型化しそれを多数連結することに よって大きな出力を得ようとするものであり，コンパクト な多自由度システムの構成に有効であると考学られる．幸 いなことに, 最近の加工技術等の急速な進歩により, 近い 将来 $\mathrm{mm}$ あるいは $\mu \mathrm{m}$ オーダのアクチュエータが実現可 能であると考えられ，分散駆動方式による多自由度システ ムの構成に大きな期待が奇せられることは間違いない22 5). 多自由度システムの理想的なモデルとしては，筋肉シス テムが挙げられる. この場合，1つの筋肉細胞が 1 つのア クチュェータに相当する. そこで, 以下では疑似筋肉シス テムの実現を目指した多自由度システムの構成法について 倹討する ${ }^{6)}$. 多数のアクチュエータによる多自由度システ ムの構成例として図 1 に示されるよらなモデルが考学られ る. 先に述べたように, 従来からロボットの駆動にはモー タのよらな回転型のアクチュェータが用いられていたが, 多自由度システムの構成にあたっては電磁石のような直動 型のアクチュエータも有用であると考えられる。なぜな ら, 回転型のアクチュェータは小型化するにつれ発生トル クが急激に小さくなり，しかも連動システムへの適用には 構造的に不自由であるといった欠点が存在するからであ る. 一方, 直動型のアクチュェータは小型化しても発生す る力が比較的大きく，アクチュエータ 1つ1つの動きが並 進運動であるため連動システムへの適用が容易である。こ こで, 直動型のアクチュエータは回転型のアクチュエータ のよらにストロークが無限にとれず，1つのアクチュエー タではギャップ長分のストロークしか持たないという久点 があるが，多くのアクチュエータを連動したシステムとす ることでストロークも大きくすることが可能である. ミリ マシン（あるいはマイクロマシン）に拈いても，直動型の アクチュエータでは静電力を利用することで出力/重量比 の大きなシステムが構築できる.これは, 物体の質量が寸 法の 3 乗, 電極間の静電力が 2 乗に比例するという特徵を 有するためであり，ミリ（マイクロ）マシンが多自由度シ ステムの構成に適している裏付けともなる.

図1（a）に示した平面モデルでは, 多自由度システムが 弾性体平板上に並ぶ多数のアクチュエータュニットから構 成されている．各ユニットの四方には直動型のアクチュ

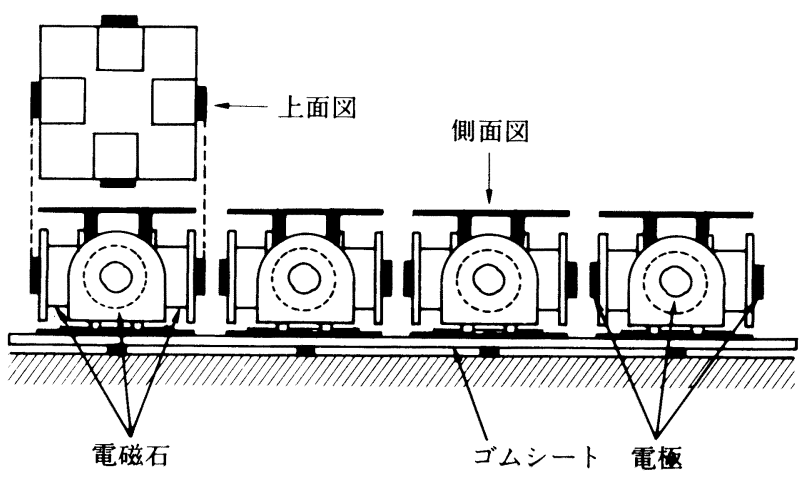

(a)

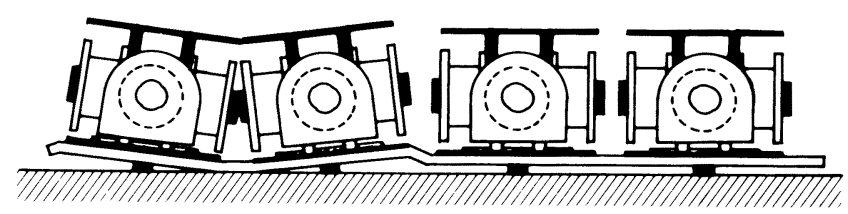

(b)

図 2 電磁石による多自由度システム（1）

エータが配置されて拈り，これらのアクチュエータが発生 する力によってシステム全体の動作が決まる. また, 図 1 （b）に示した空間モデルは，弾性体の円柱に配置される上

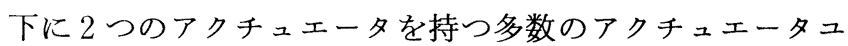
ニットからなる．空間モデルに拈いても平面モデル同様, 各アクチュエータに作用する力によってシステム全体の動 作が決定される.この空間モデルは図 1 (a) に示した平面 モデルを円筒状に巻いたモデルと等価とも言える. これら のモデルは, 筋肉システムの伸縮運動に倣って構成された 多自由度システムである，以下では，これらのモデルを電 磁石を用いて実現し，その運動学解析を試みる．さらに, ミリマシンから半導体加工技術を利用したマイクロマシン による多自由度システムの構成例についても簡単に示す。

\section{2 電磁石を用いた多自由度ミリマシンシステムの構 成}

前節で示した多自由度システムを電磁石を用いて構成し た例を図 2 に示す。ここで，システムの構成は四方に 4 つ の電磁石を持つ 16 個のユニットからなる. この平面モデ ルを用いて図 3 に示される (b), (c), (d) の順に電磁石を 励磁すると，ユニット (1)-(2) 間 $\rightarrow(2)-(3)$ 間 $\rightarrow(3)-(4)$ 間の伸縮が繰り返され，平面モデルは 1 サイクルの励磁に より距離 $d$ だけ移動することになる.ここで, システム の全長 $l_{\mathrm{a}}$ 抌よび移動距離 $d$ は次式により表される.

$$
\begin{aligned}
& l_{\mathrm{a}}=4 l+3 g \\
& d=2 l(1-\cos \theta)
\end{aligned}
$$

さらに，図1(b) に示した空間モデルを電磁石を用いて 構成すると図 4 のようになる. 本システムは, 12 個のユ ニットからなり, 平面モデル同様各ュニットには四方に電 磁石が取り付けられている. また, 両端以外のユニットは

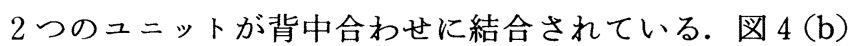




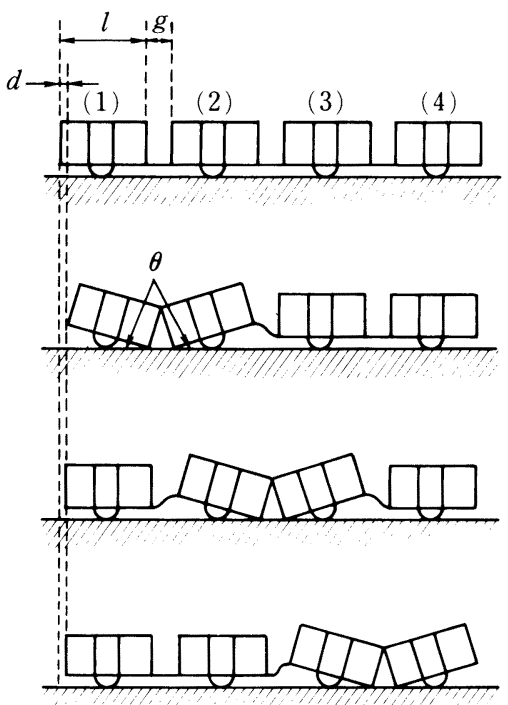

(a)

(b)

(c)

(d)

図 3 平面モデル動作指令の例

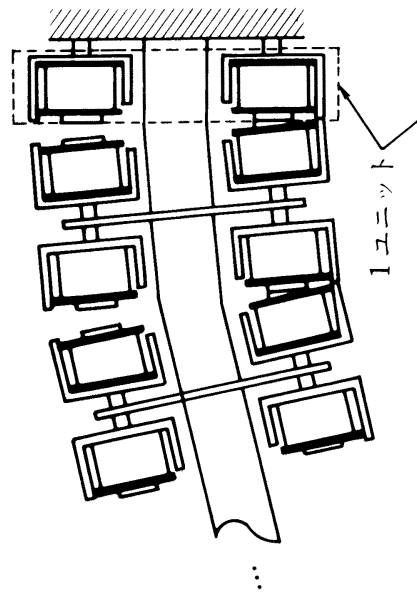

(a)

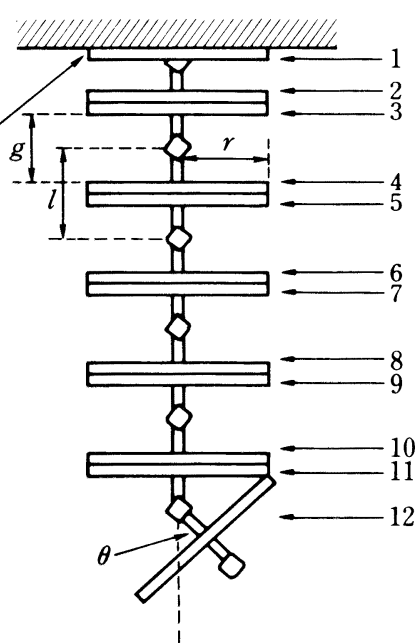

(b)
図4 電磁石による多自由度システム（2）

より，第 $n$ 段目の先端のずれは次式のように表され，電 磁石の励磁により任意方向への動さが可能となる.

$$
\begin{aligned}
& z_{n}=\sum_{k=1}^{n} l \sin k \theta \quad(n=1 \sim 6) \\
& \theta=2 \tan ^{-1}\left(\frac{g}{2 r}\right)
\end{aligned}
$$

図 2 および図 4 に示した多自由度システムについて, 実 際の実験を通して各モデルの運動解析を行う。まず, 平面 モデルを用いて行った実験結果を示す．実験システムの概 略図は図 5 に示す通りであり, 計算機内で決められた動作 指令に応じた ON/OFF 信号が，I/O ボードを経て電磁石 励磁のスイッチングパターンとして各アクチュエータへ送 られている. 従って, システム全体の動作は送られるス イッチングパターンによって決まる. 例えば, 表 1 に示さ れるスイッチングパターンによって得られた実験結果を表 2 に示す。これより, 平面モデルでは 3 自由度分（2つの 並進運動と 1 つの回転運動）の動作を実現することができ
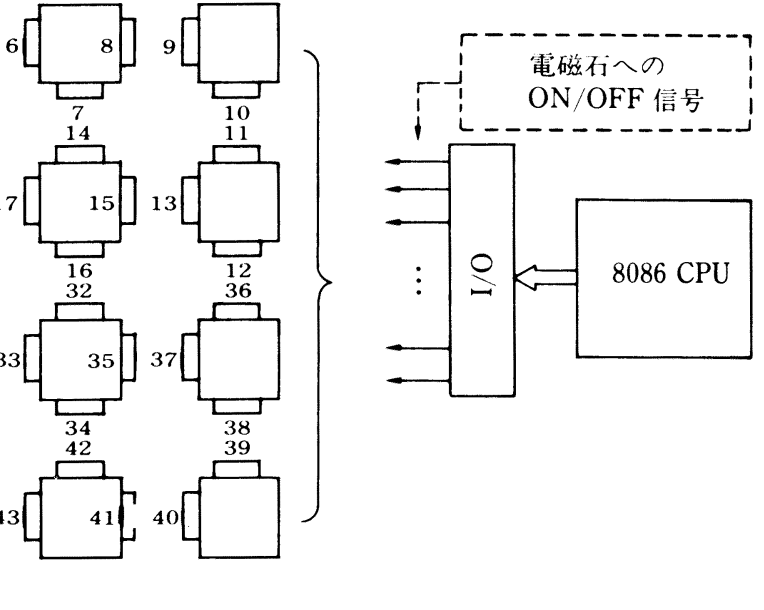

図 5 平面モデルの央験システム

\begin{tabular}{|c|c|c|}
\hline パターン 1 & $\begin{array}{l}\text { (1) } 2,3,21,23,27,29,46,47 \\
\text { (2) } 5,6,17,19,31,33,43,44 \\
\text { (3) } 8,9,13,15,35,37,40,41\end{array}$ & \\
\hline パターン 2 & $\begin{array}{l}\text { (1) } 26,30,34,38,39,42,45,48 \\
\text { (2) } 12,16,20,24,25,28,32,36 \\
\text { (3) } 1,4,7,10,11,14,18,22\end{array}$ & \\
\hline パターン 3 & $\begin{array}{ll}\text { (1) } 2,3,17,19 & \text { (7) } 31,33,40,41 \\
\text { (2) } 5,6,17,19 & \text { (8) } 31,33,43,44 \\
\text { (3) } 8,9,17,19 & \text { (5) } 12,16,32,36 \\
\text { (4) } 10,11,16,32 & \text { (6) } 16,32,38,39\end{array}$ & $\begin{array}{l}\text { (9) } 31,33,46,47 \\
\text { (10) } 20,28,26,48 \\
\text { (11) } 20,24,25,28 \\
\text { (12) } 1,20,22,28\end{array}$ \\
\hline
\end{tabular}

表 1 平面モデル動作指令の一例

表 2 平面モデルを用いた丰験結果

\begin{tabular}{l|c|c|c}
\hline & パターン & パターン2 & パターン3 \\
\hline スイッチングサイクル & $2.5 \mathrm{~Hz}$ & $2.5 \mathrm{~Hz}$ & $0.8 \mathrm{~Hz}$ \\
速 度 & $80 \mathrm{~mm} / \mathrm{min}$ & $80 \mathrm{~mm} / \mathrm{min}$ & $0.042 \mathrm{rad} / \mathrm{min}$ \\
動 作 & 亚進 & 亚進 & 问転 \\
タイプ & $x$ & $y$ & 右旋回 \\
\hline
\end{tabular}

る.

次に，空間モデルを用いて行った実験結果を示す。図6 が空間モデルの実験システムであり, 各アクチュエータに は平面モデル同様, 所望する動作に応じた ON/OFF 信号 が送られる．表 3 にスイッチングパターン例を示す。 た, このスイッチングパターンに従って得られた実験結果 を表 4 にまとめる.

表 2 あるいは表 4 に示される実験結果より, 平面あるい は空間モデルに拈いて，各アクチュエータへ送られるス イッチングパターンに応じて並進あるいは回転動作が実現 できることが分かる．ここでは，アクチュエータとして小 型の電磁石を用いたため, その発生力が小さく, 速い動作 や大きな動作を実現することは出来なかったが，静電アク チュェータに代表される発生力の大きなアクチュェータを 多数連結することによって速い動作や大きな動作の実現も 期待できる. そこで, 次章では半導体加工技術を利用した マイクロマシンによる多自由度システムの構成例について 示す. 


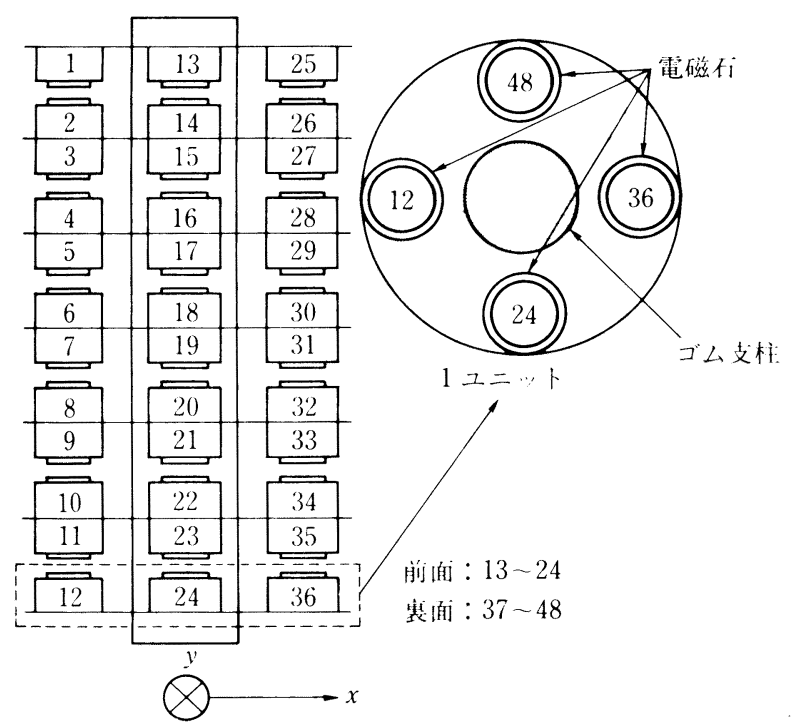

図 6 空間モデルの実験システム

\begin{tabular}{c|l} 
表 3 & \multicolumn{2}{c}{$\begin{array}{l}\text { 空間モデル動作 } \\
\text { 指命の一例 }\end{array}$} \\
\hline パターン 1 & (1) 7,8 \\
& (2) $7 \sim 10$ \\
& (3) $7 \sim 12$ \\
& (4) 31,32 \\
& (5) $31 \sim 34$ \\
& (6) $31 \sim 36$ \\
\hline パターン2 & (1) 19,20 \\
& (2) $19 \sim 22$ \\
& (3) $19 \sim 24$ \\
& (4) 43,44 \\
& (5) $43 \sim 46$ \\
& (6) $43 \sim 48$ \\
\hline
\end{tabular}

表 4 空間モデルを用いた奏験結果

\begin{tabular}{l|l|rrr}
\hline & 移動方向 & \multicolumn{2}{|c}{ 移 動 } & 距 離 \\
\hline パターン 1 & $+x$ & $-x$ & $8.8 \mathrm{~mm}$ & $-10.0 \mathrm{~mm}$ \\
パターン 2 & $+y$ & $-y$ & $11.2 \mathrm{~mm}$ & $-9.4 \mathrm{~mm}$ \\
\hline
\end{tabular}

\section{3 ミリマシンからマイクロマシンヘ (?)}

前述した，多自由度システムに拈けるアクチュェータの 特徵をるとめると以下のことが言える.

・微細化に適している.

・直並列に連結することができる.

・制御性がよい.

以上の条件を打扰よそ満足するアクチュエータとして， 近年注目されているマイクロアクチュエータがあげられ る. 本節では, 図 1 に示した多自由度システムのアクチュ エータユニットとしてマイクロアクチュエータの製作過程 の一例を紹介する．ここで，アクチュエータとしては図 7 に示されるよらに一対の櫛形電極がポリイミドの薄膜に よって支持されたものを考える7).さらに，ポリイミド薄 膜上にアルミニウム配線を施すことによってアクチュェー

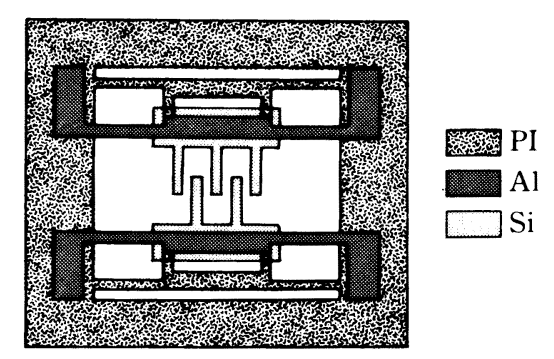

図 7 櫛形静電マイクロアクチュエータの構造
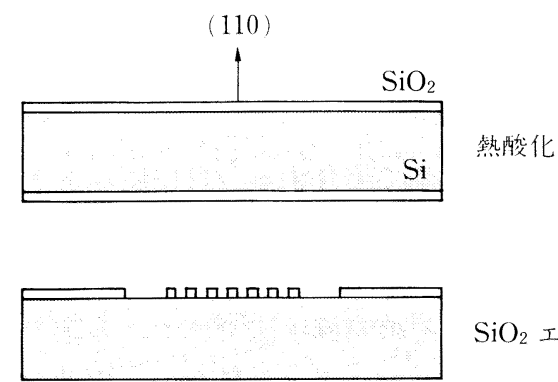
$\mathrm{SiO}_{2}$ エッチンク

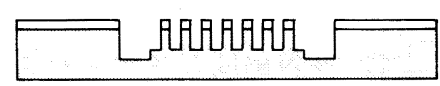
買ノj性:エッチンク

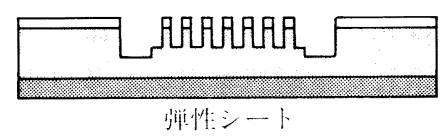

弹性:体膜形成

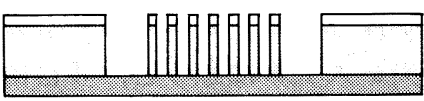

ブラズマエッチンク

タの駆動を可能にする.

図 7 に示すマイクロアクチュエータの製作プロセスを図 8 に示す. マイクロアクチュエータの製作に招いて，その 製作過程が重要であることは言うまでもないが，材料の選 定もアクチュエータ製作の重要な鍵となる. 例えば, 上記 の櫛形静電マイクロアクチュェータに拈いてはアクチュ エータを支持する弾性材料はヤング率が大きく, 電気絶縁 性が高いものが望まれる. 比較的ヤング率の大きな弾性体 を用いると, アクチュエータの固有周波数が増し高速な動 作の実現を可能にする，また，静電アクチュエータは，そ れぞれの電極に蓄積された電荷同士の吸引力を利用して駆 動するアクチュエータであるため, それぞれの電極間を良 好に絶縁しなければならない，そこで，電気絶縁性の良い 材料を選択することによりアクチュェータを低損失, 高効 率に駆動することが可能となる.

今回示した櫛形静電マイクロアクチュエータでは，ポリ イミドを用いた製作プロセスを紹介した。 ポリイミドは耐 熱性, 耐摩耗性, 絶縁性に優れている特徵を有する一方, 強酸, 強アルカリによって加水分解されてしまうため, 製 
膜後にウェットェッチングプロセスを用いられない等の 制約を受ける。また，一般にマイクロマシンにおいては 慣性力に比し摩擦力の影響が非常に大きくなり, 非線形 性が増してしまうことも指摘されている $\mu \mathrm{m}$ オーダの小形アクチュエータの必要性拉よび構成 法に関しては，今後議論すべき多くの問題を有する．し かしながら, 多自由度システム構成用の高効率小形ア クチュエータの実現にミリ（あるいはマイクロ）マシン が有用であり必要不可欠となることは強調したい。

\section{3. 多自由度システムの制御}

先に述べたように，本稿で紹介する多自由度システムの 目的はミリマシンによってマクロな動作を実現しようとす るものである。従って，多自由度システムを実現した場 合，次に問題となるのはとの制御手法である．多数のアク チュエータを導入することでロボット自身の自由度を増す ことはできるが，従来のロボットの制御系のように個々の アクチュエータを独立に制御しょらとすると制御系が急速 に複雑化してしまう。そこで, 多自由度システムの制御に おいては従来の制御手法とは異なる新たな手法を適用する 必要がある. 筋肉組織をみても個々の細胞は独立にコント ロールされているわけではなく，動作信号が伝搬する機構 となっている．第 2 章で示した電磁石を用いた多自由度シ ステムに执いては, 個々のアクチュエータは動作パターン に応じた ON/OFF 信号によりスイッチングされていた が，実際にはこのような動作パターンを伝搬させる機構を 実現する必要がある。筋肉システムに倣らと, 多自由度シ ステムのアクチュエータ1つ1つは精確に制御されるわけ でなく，前段のアクチュエータから転送されてきた動作信 号を次段のアクチュエータへ転送する役目を担うことにな る.このように，アクチュェータを動作信号伝搬のメディ アとして用いることによって，制御系全体の簡略化を図る ことができる，これは，多自由度システムの制御に沶いて 重要なコンセプトとなる．紙数の関係上，以下では制御法 の概念だけを簡単に紹介する ${ }^{6}$. 特に，動作信号として力 伝搬機構を実現するための基本アルゴリズムを述べる。こ こで，力伝搬機構を実現するため非線形系のもつ特性を利 用する。多自由度システムを制御するにあたって個々のア クチュエータを線形制御に基づき精確に制御することは, 先に述べたようにシステムの複雑化を招く．その上，動作 信号を伝搬する機構にすると系の持つ分散関係の影響で指 令信号（ここでは，孤立パルスをさす）をその形状を維持 したまま伝搬させることが不可能となる。一方，非線形 フィードバックに基ついた非線形系では, 系のポテンシャ ル関数を式 (5) のように設定（非線形制御によりこのよう な設定は可能である）することで力信号が孤立波（ソリト ン）として伝搬する非線形システムを実現することができ る.

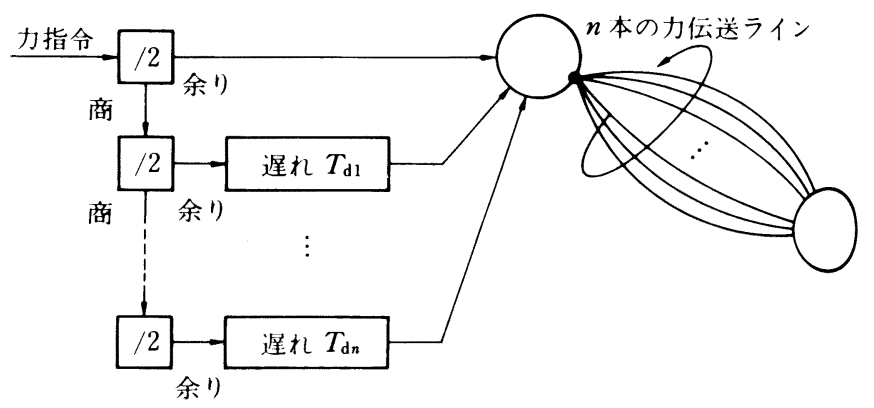

図 9 力伝送の基本アルゴリズム

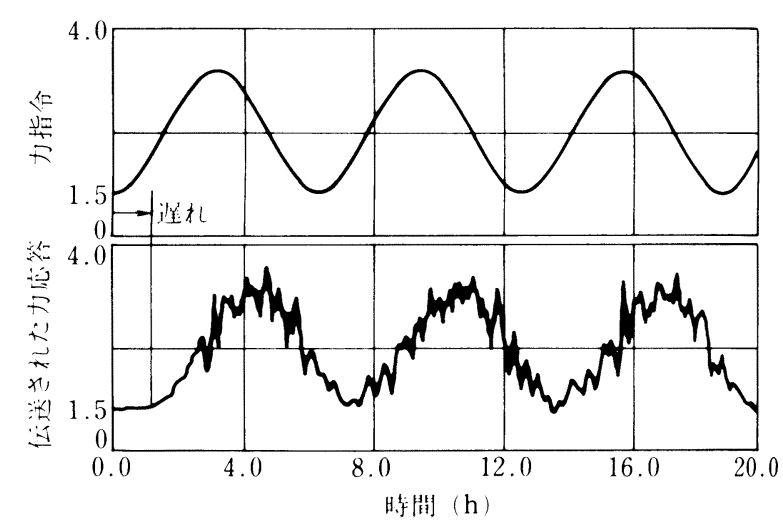

図 10 シミュレーション結果

$$
\phi\left(r_{n}\right)=\frac{a}{b} e^{-b r_{n}}+a r_{n} \quad(a b>0)
$$

式（5）に基ついいた非線形制御系により力の伝搬機構が実 現されると，一例として図9に示すような力伝送アルゴリ ズムによって力の制御が可能となる. 同図では, 2 つ質 点が $n$ 本の非線形多自由度アクチュエータにより連結さ れ，伝送すべき力指令が 2 進の $n$ ビットに分解表現され ている.さらに, 各ビットの力信号が別々の非線形多自由 度アクチュエータにより伝送される. 非線形系に拈けるy リトンの伝搬速度は力信号の振幅に依存する. そこで, 各 ビットごとに時間遅れを挿入することで終端への力信号の 伝送時間が同一となるように調整される，これにより，終 端に加わる力は各非線形多自由度アクチュエータにより伀 送される力の総和となる. 図 9 に示す力伝送アルゴリズム は, 力の遅れ制御といら観点から遅れ力重畳法 (Delay Superposition Method: DSM) と呼ぶ. 図 10 にDSM に より伝送された力応答のシミュレーション結果を示す. 同 結果より, 正弦波力指令に応じた力応答が得られているこ とが分かる. ここで, 力伝送の遅れは基本波（伝搬速度が いちばん遅い孤立波）に依存する。図 9 のアルゴリズム は, 多自由度システムに打ける動力学を扱っており, シス テム全体を制御する場合には運動学を考慮したアウタルー プ (位置, 速度, 加速度, 力のフィードバック) が必要と なる。

上記に示した非線形制御系は多自由度システムの一制御 法にすぎないが, 分散駆動の観点からは今後期待される制 御手法と考えられる. 分散駆動方式では, 集中駆動方式の 
欠点ともいえる故障問題をもある程度改善することができ る. 集中駆動方式による現在のロボットでは，特に基準座 骠に近い駆動アクチュェータが故障するとロボットとして の機能が亚失してしまう。しかしながら, 図 9 に示される 力层送アルゴリズムに基づく分散駆動方式では，故障箅所 により出力できる力の大きさは制限されるものの, 非線形 多自由度アクチュエータのいずれかが故障したとしても， システム全体が機能しなくなることはない，これは，我々 が直感的に理解できる筋肉システムの機能と合致する点で もある。

\section{4. おわりに}

以上：ミリマシンを用いた新たなロボットの機構技術を 紹介した。従来のロボット開発のように，マクロな動作は マクロロボットで, ミクロな動作はマイクロロボットで, といらような目的に応じたロボット機構では多機能な口 ボットの実現は望めない。このよらな観点から，本稿では ミリマシンによる多自由度システムの構成法を示し, 多自 由度システムによるマクロ動作の実現法を示した。
ミリ（あるいはマイクロ）マシンによるアクチュエータ の製作に関しては, 今後多自由度システムへの拡張が重要 な課題として考兄られる. また，その制御手法の開発も今 後の展開に期待するところが大きい。

\section{参 考 文 献}

1) K. Ohnishi et al. : Applications of Advanced Control Techniques in Electrical Drives, IEEE. Int., Workshop on Microcomputer Control of Electrical Drives, (1989) 1.

2) 日本ロボット学会誌：[特集] マイクロマシンとマイクロメカ ニズム, 8, 4 (1990).

3) W. Trimmer: Micromechanical Systems, The Third Toyota Conf., Integrated Micro Motion Systems, (1989) 11.

4) Long-Shen Fan et al. : IC-processed Electrostatic Micromotors, Sensor and Actuators, 20, (1989) 41.

5) K. E. Petersen : Dynamic Micromechanics on Silicon: Techniques and Devices, IEEE Trans. Electron Devices, ED-25, 10, (1978) 1241.

6) 村上俊之, 石橋宏純, 大西公平: 疑似筋肉システムの一構成 法, 電気学会論文誌 D, 111-D, 12, (1991） 000 .

7) F. Fujikawa et al. : Fabrication of Comb-Shaped Microactuator for Multi-Degrees-of-Freedom System, IEEE. Int., IECON '92, Vol. 2, (1992) 990. 